Document downloaded from:

http://hdl.handle.net/10251/93270

This paper must be cited as:

Sierra Varela, LA.; Yepes Piqueras, V.; Pellicer Armiñana, E. (2017). Assessing the social sustainability contribution of an infrastructure project under conditions of uncertainty. Environmental Impact Assessment Review. 67:61-72. doi:10.1016/j.eiar.2017.08.003

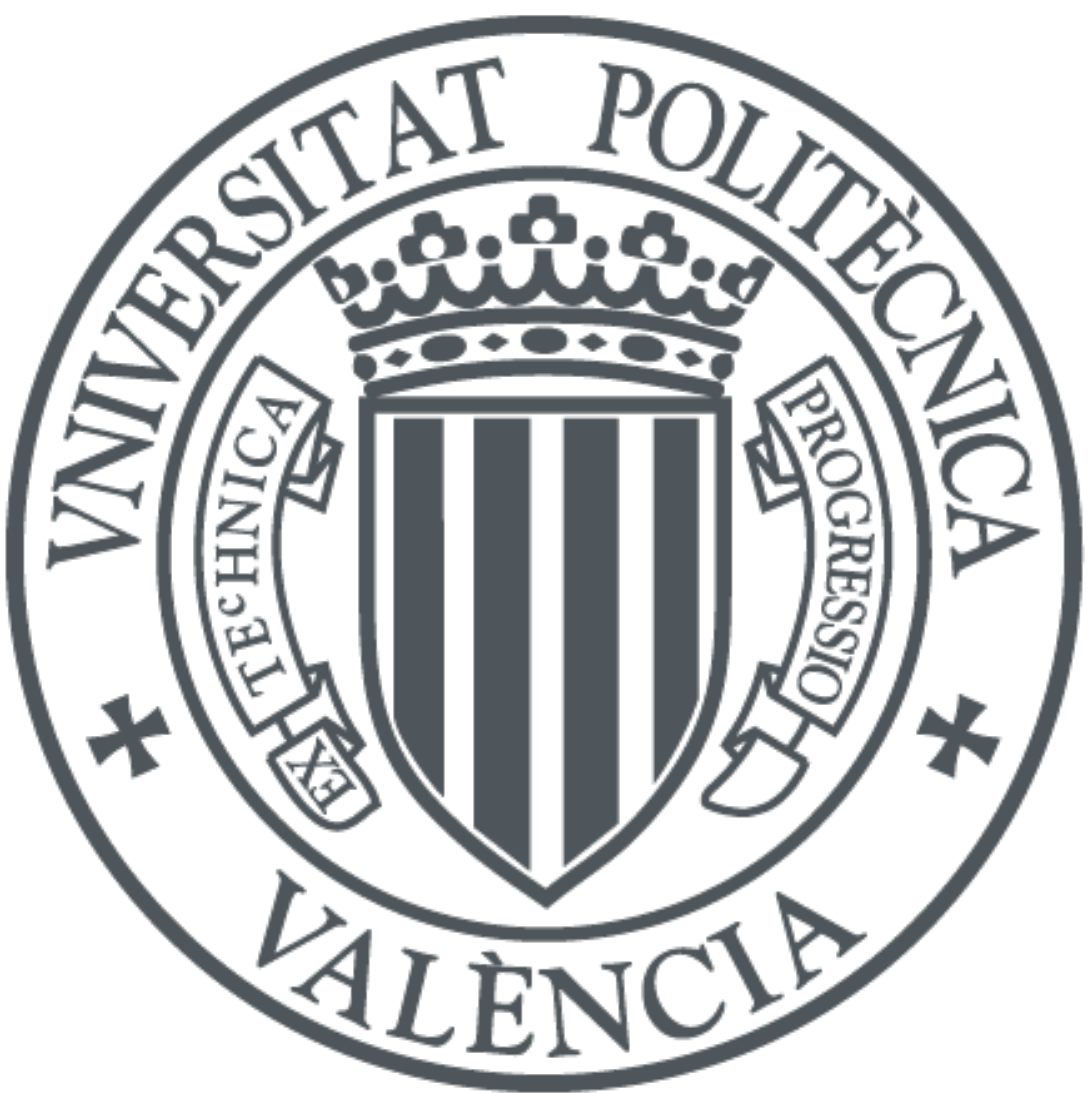

The final publication is available at

https://doi.org/10.1016/j.eiar.2017.08.003

Copyright Elsevier

Additional Information 


\title{
ASSESSING THE SOCIAL SUSTAINABILITY CONTRIBUTION OF AN INFRASTRUCTURE PROJECT UNDER CONDITIONS OF UNCERTAINTY
}

\author{
SIERRA, L.A.; YEPES, V.; PELLICER, E. \\ Universitat Politècnica de València
}

\begin{abstract}
Assessing the viability of a public infrastructure includes economic, technical and environmental aspects; however, on many occasions, the social aspects are not always adequately considered. This article proposes a procedure to estimate the social sustainability of infrastructure projects under conditions of uncertainty, based on a multicriteria deterministic method. The variability of the method inputs is contributed by the decision-makers. Uncertain inputs are treated through uniform and beta PERT distributions. The Monte Carlo method is used to propagate uncertainty in the method. A case study of a road infrastructure improvement in El Salvador is used to illustrate this treatment. The main results determine the variability of the short and long-term social improvement indices by infrastructure and the probability of the position in the prioritization of the alternatives. The proposed mechanism improves the reliability of the decision making early in infrastructure projects, taking their social contribution into account. The results can complement environmental and economic sustainability assessments.
\end{abstract}

KEYWORDS: Infrastructure; Multicriteria Decision-Making; Uncertainty; Social Sustainability

\section{Introduction}

The social dimension is a pillar of sustainable development together with the economic and environmental aspects. Yet the treatment of the social dimension is less evolved (Valdés-Vásquez and Klotz 2013, Dominguez-Gomez 2016). Several methods have focused on identifying the environmental and economic impacts of infrastructure projects, without explicitly considering their social approach (Ahmadwand and Karami 2009, Penades-Pla et al. 2016, Karami et al. 2017). Social assessment is an overarching framework that embodies the evaluation of all impacts on humans and on the ways in which people interact with their socio-cultural, economic and biophysical surroundings (Vanclay 2002, 2003). Specifically, Vanclay (2002) identifies seven categories social impacts that could be considered in an assessment: health and social well-being; liveability; economic and material well-being; cultural; family and community; institutional, political and equity; and gender relations.

In the last decade some initiatives have been proposed that take into account the assessment of the social contribution. In the MIVES ("Integrated Value Method for Sustainability Assessments"), a function proportional to the satisfaction of the beneficiaries deals with the social aspects (Gómez-López et al. 2013). In the SUSAIP ("Sustainability Appraisal in Infrastructure Projects"), the social aspects are treated homogenously in different regional contexts and the stakeholders are considered less in the decision-making (Ugwu et al. 2006). In the TSI ("Technical Sustainability Index"), the immediate impacts are not considered and aspects like health, wealth and politics are 
treated within a set of environmental indicators (Dasgupta and Tam 2005). In addition, some sustainability rating systems such as ENVISION, CEEQUAL or IS have included social aspects in their evaluations. However, these are more appropriate for developed countries, and they give less importance to the social aspects (Diaz-Sarachaga et al. 2016).

In most of these proposals, the social aspects have been interwoven with environmental assessment methods to measure sustainability. Moreover, the little familiarity and the difficulty in dealing with the social aspects mean they are taken less into consideration (Pope et al. 2004, Pellicer et al. 2016). The heterogeneity of regional development or the impossibility of standardizing an impact in different contexts are relativized aspects in the usual methods (Esteves and Vanclay 2009). Indeed, the interaction between infrastructure type and location context affects its social contribution. Normally, the contribution to social improvement in the short and long term justifies the decisionmaking of a public project. Yet the two approaches are not necessarily given simultaneously (Gannon and Liu 1997). In a short-term approach the early return of the social benefits of an infrastructure is only possible in a consolidated context. By contrast, a long-term approach concentrates on the contexts with the greatest social weaknesses and greater potential contribution to improvement (van de Walle, 2009) .

A multicriteria deterministic method was recently proposed to assess social sustainability in infrastructure projects (Sierra et al. 2017). This method is structured in three processes that determine (a) a short-term social improvement index; (b) a longterm social improvement index; and (c) a multi-objective prioritization of the public infrastructure investment alternatives. Short-term social improvement identifies an infrastructure's contribution in interaction with the present context. In this study, the short term considers the social effects of infrastructure planning, design and construction up to approximately three years from the start of the operation. On the other hand, in the long term, the distribution impact of the benefit considers the zones with social need. The long term considers the social effects on the type of tenure and preservation of the infrastructure. Once the social improvement for the different alternatives has been identified, these can then be prioritized according to their contribution to social sustainability.

However, the social contribution requires an assessment of qualitative and quantitative aspects, the impact of which on well-being and social development is not predetermined (Valdés-Vásquez and Klotz 2013, Sierra et al. 2016, 2017). In this sense, the specific characteristics of a project have a high degree of uncertainty in the viability phase (Pan 2009, Cardenas and Halman 2016). In the design and construction phases of an infrastructure, contingencies arise, the determinist assessment of which is not reliable in the early stages (Gervasio and Simoes da Silva 2012). Specifically, the local or regional sources of information make it possible to establish the variability of certain social aspects. The social databases related to infrastructures and particularly qualitative aspects, however, are still nascent (Labuschagne and Brent 2006, Sahely et al. 2005). Therefore, the experience of local experts can be a source of information that can be modeled to deal with the uncertainty (de la Cruz et al. 2015).

Therefore, in line with the previous points, the social aspects require adequate treatment in the evaluation of sustainability. In this vein, Sierra et al. (2017) proposed a deterministic evaluation method of the social sustainability of infrastructures in the 
short and long term. However, assessing the social aspects requires a procedure to deal with their uncertainty (Gervasio and Simoes da Silva 2012, Cárdenas and Halman 2016). This is the starting point of the present study. Given the above, this paper proposes an additional treatment to estimate the contribution to the social sustainability of infrastructure projects under conditions of uncertainty.

The article debates, first of all, the techniques to treat uncertainty addressed in this work. Next the method for assessing the social sustainability of infrastructures as proposed by Sierra et al. (2017) is presented. Then the proposal to deal with the uncertain variables within the evaluation method is described step-by-step. The proposed treatment is illustrated through a case study. Finally, the contributions, limitations and future lines of research are presented in the conclusions.

\section{Dealing with uncertainty}

In the viability phase of the service life of a public project, different infrastructure alternatives are assessed. In this phase the social aspects are important due to their vagueness and uncertainty of their effects on society (Gervasio and Simoes da Silva 2012). The uncertainty can be internal or external. The first takes into account the variability of the method to be used and the input data. External uncertainty refers to the lack of knowledge about a choice (Gervasio and Simoes da Silva 2012).

Multicriteria decision-making requires consideration of the weights of each criterion and the assessment of these criteria for each alternative (Zamarron-Mieza et al. 2017). In each of these processes there are uncertain variables that can be defined by ranges of behavior expected according to a probability (Jato-Espino et al. 2014). When the amount of data available is not sufficient for a classic probabilistic adjustment, a discrete uniform distribution can be used (Gervasio and Simoes da Silva 2012). In other cases, knowledge and experience can permit the maximum and minimum parameters and the mode that describes a triangular distribution to be known (de la Cruz et al. 2015). Alternatively, the parameters of a triangular distribution can be assimilated to a beta PERT distribution. This function allows a greater ease of use and a more real continuity in the adjustment of the turning points (Jato-Espino et al. 2014).

In addition, a method widely used to give functionality to the simultaneous propagation of uncertainty through decision-making processes is the Monte Carlo method (Gervasio and Simoes da Silva 2012, de la Cruz et al. 2015). The Monte Carlo method can be used as a risk management tool that aims to elicit the probability of contributing a series of achievements for a certain alternative (Jato-Espino et al. 2014). Thus, from a set of random variables, with specific and iterative distributions, it is possible to control the uncertainty of the set of decision-making alternatives.

\section{Estimation method of the social sustainability of infrastructures.}

This method for estimating sustainability includes an approach for short and long-term social improvement and prioritization. The second and third column of Fig. 1 illustrate the processes that intervene in the evaluation method. The processes called " $\mathrm{A}$ " and "B" intervene in short and long-term social improvement, respectively. The process " $\mathrm{C}$ " weighs the results of "A" and "B", and determines the prioritized solution of socially 
sustainable alternatives. In line with Sierra et al. (2017), the stages that determine the method are presented as follows.

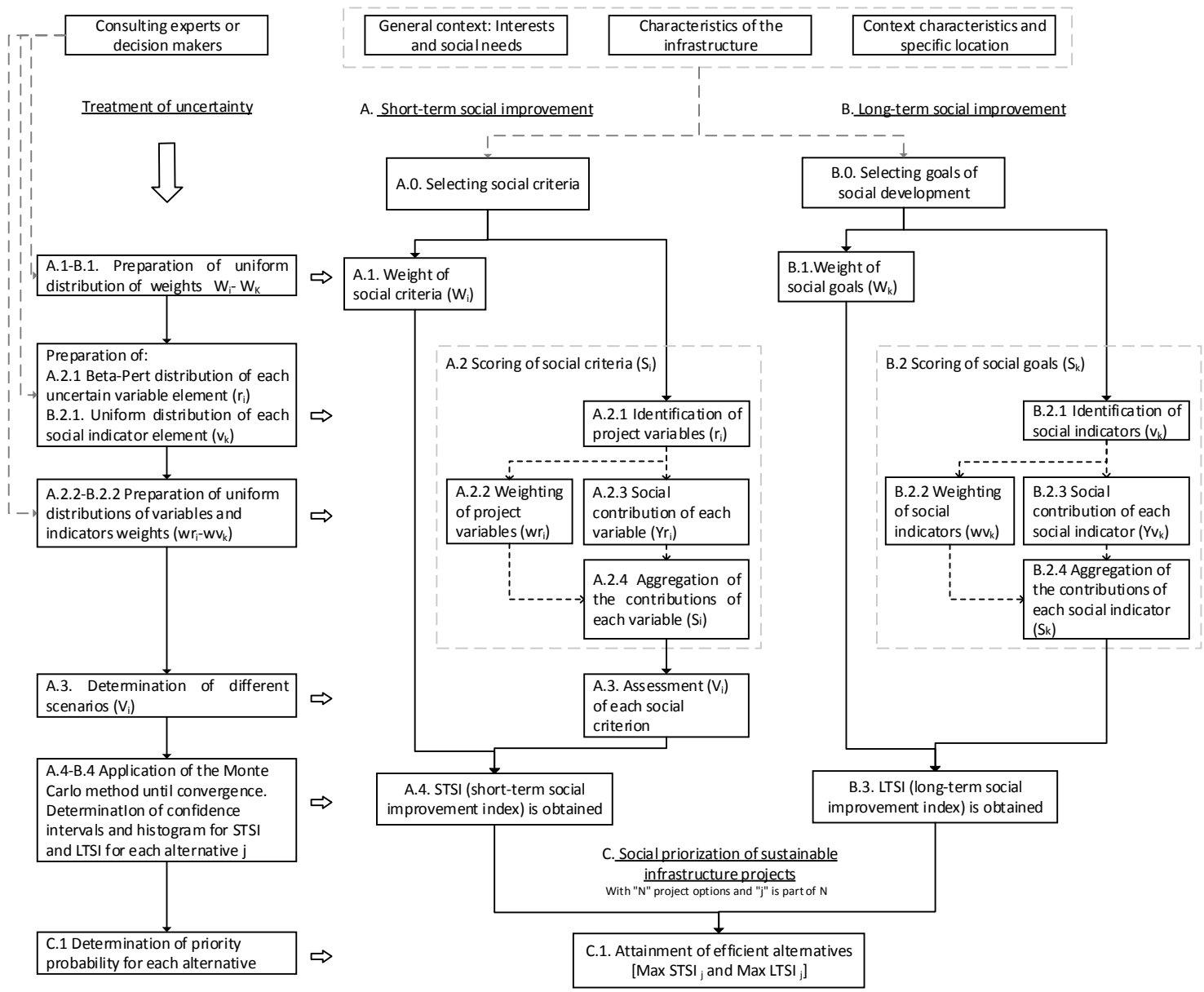

Fig. 1: Method for estimating the social contribution considering the uncertainty (adapted from Sierra et al. 2017)

Stages A.O and B.O: A set of multidisciplinary decision-makers selects the criteria and social goals according to the set of infrastructures and the context. To approximate a consensus the Delphi method is applied. The profile of the decision-makers is adjusted to the suggestions by Hallowell and Gambatese (2010) to guarantee the rigor of the method.

Stages A.1 and B.2: The set of decision-makers determines the weights of the criteria and social improvement objectives. The decision-makers compare the importance between pairs of criteria and among social goals through an Analytic Hierarchy Process (AHP) (Saaty 1987).

Stages A.2.1 and B.2.1: For each criterion $i$ and objective $k$ the project variables $r_{i}$ and indicators of the zone $v_{k}$ are identified, respectively. Both the variables and the indicators must potentially be influenced in the lifecycle of the infrastructure. In addition, the effect of each variable $r_{i}$ is determined by conditioning factors of the zone $c_{i r}$ that are identified. The selection of the variables $r_{i}$, the conditioning factors $c_{i r}$ and the indicators $v_{k}$ are the result of a field study and the consensus of the decision-makers. 
Stages A.2.2 and B.2.2: The group of decision-makers determines the weights of the variables of the project $w_{r i}$ and social indicators $w_{k v}$. The decision-makers compare dually the importance between criteria and indicators by applying the AHP method.

Stages A.2.3 and B.2.3: The project variable $r_{i}$ and social indicator $v_{k}$ determine the social contribution $Y_{i r}^{s t}$ and $Y_{k v}^{l t}$, respectively. For each project variable $r_{i}$ and its conditioning factors from the zone $c_{i r}$, a transference function is formulated. The transference functions are interpolation functions. The functions transform the qualitative and quantitative inputs to a value $Y_{i r}^{\text {st }}$ of 0 (no contribution) to 100 (maximum contribution). In turn, for each indicator $v_{k}$ the degree of future benefit of the project $Z_{k v}$ is determined, as well as the degree of current weakness of the zone $C_{k v}$. The values of $Z_{k v}$ and $C_{k v}$ are agreed upon by the decision-makers on a scale from 1 (minimum benefit/weakness) to 5 (maximum benefit/weakness). Thus, the value of $Y_{k v}^{l t}$ is the product between $Z_{k v}$ and $C_{k v}$ for each indicator $v_{k}$.

Stages A.2.4 and B.2.4: The social contributions $Y_{i r}^{s t}$ and $Y_{k v}^{l t}$ of a project are added to a score by criterion and social goal. The simple additive weight of the contributions $Y_{i r}^{s t}$ and $Y_{k v}^{l t}$ determine a score by criterion $S_{i}^{s t}$ and social goal $S_{k}^{l t}$, respectively. The values of $S_{i}{ }^{s t}$ are contained in the intervals of [0-100]. In turn, $S_{k}{ }^{l t}$ is contained in the interval [1-25].

Stage A.3: A function revalues the score of each short-term social criterion $\left(S_{i}^{s t}\right)$ according to what the context demands. Alarcón et al. (2011) and Gómez-López et al. (2013) developed a generic value function to estimate the satisfaction of attributes. This function can be used for different levels of social requirement. In effect, a concave shape represents a low demand, i.e., high satisfaction can be reached with few improvements. A convex shape represents a high demand, i.e., large improvements are required to reach a high level of satisfaction. A linear shape represents a moderate demand, i.e., satisfaction is proportional to the improvement. Eq. [1] represents the value function indicated, with $V_{i}$ being the value of each criterion $i$. The parameters $m_{i}$, $n_{i}$ and $A_{i}$ define the convex $\left(A_{i} \geq 2, m_{i} \leq 0.1, n_{i} \geq 45\right)$, concave $\left(A_{i} \leq 0.75, m_{i} \geq 0.9, n_{i} \approx 100\right)$, or linear $\left(A_{i} \approx 1, m_{i} \approx 0, \mathrm{n}_{\mathrm{i}} \approx 15\right)$ shape of the criterion. $K_{i}$ limits the result interval of the function from $0\left(S_{i}^{s t}=0\right)$ to $1\left(S_{i}^{s t}=100\right)$ (Manga 2005).

$$
V_{i}=K_{i} \cdot\left[1-e^{-m_{i}\left(\frac{s_{i}^{s t}}{n_{i}}\right)^{A_{i}}}\right]
$$

Stages A.4, B.3: For each project, the values of $V_{i}$ and $S_{k}^{l t}$ are added to a short-term social improvement index (STSI) and long-term social improvement index (LTSI), respectively. The STSI and LTSI are the result of simple additive weight of $V_{i}$ and $S_{k}^{l t}$, respectively. The STSI varies on a scale from 0 to 1 , and reflects the integrated contribution of an infrastructure in the short term. The LTSI varies on a scale from 1 to 25 and reflects the potential strengthening of the social weaknesses in the long term.

Stage C.1: The optimization techniques have proven to be an efficient system to discriminate sustainable alternatives (Torres-Machi et al. 2017). In that case, the prioritization of the infrastructure projects derives from the multi-objective optimization that maximizes the STSI and LTSI. A compromise programming method that determines the smallest Chebyshev distance $d_{\infty}$ to an ideal point establishes balanced solutions 
(Yepes et al. 2015). Eq. [2] represents the formula of the compromise programming for this method. $S T S I_{j}, L T S I_{j}$ represent the values of the indices of each $j^{\text {th }}$ alternative. $\lambda_{1}, \lambda_{2}$ are the weighting of the improvement indices; STSI* ${ }^{*}$ LTSI$^{*}$ represent an ideal point and $S T S I_{*}, L T S I_{*}$ the anti-ideal point of the short and long-term social improvement, respectively.

$\operatorname{Min} d_{\infty} ; \quad d_{\infty j}=\operatorname{Max}\left[\lambda_{1} \cdot\left(\frac{S T S I^{*}-S T S I_{j}}{S T S I^{*}-S T S I_{*}}\right) ; \lambda_{2} \cdot\left(\frac{L_{T S I}^{*}-L_{T S I}}{L_{T S I^{*}}-L_{T S I}}\right)\right]$

\section{Treatment of uncertainty proposed for the assessment of social sustainability of infrastructures.}

Next, the treatment of the uncertainty incorporated into the method for estimating the social sustainability of infrastructure projects is detailed. This procedure makes it possible to control the risk in prioritizing a set of infrastructure projects. The distributions of the social improvement indices determine the probability of the order of priority of each project. The parameters dealt with according to this mechanism are: (1) all the weights involved in the method $\left(W_{i}, w_{i r}, W_{k}, w_{k v}\right)$; (2) the variables of the project $\left(r_{i}\right)$ and influential conditioning factors $\left(c_{i r}\right)$ categorized as uncertain by the experts and (3) degree of potential benefit from the infrastructure $\left(Z_{k v}\right)$ and the degree of zonal need $\left(C_{k v}\right)$ for each long-term indicator. The first column in Fig. 1 shows the flow of the procedure to control the internal uncertainty in processes $\mathrm{A}, \mathrm{B}$ and $\mathrm{C}$ of the method. The following paragraphs describe the treatment of the uncertainty in the method.

\subsection{Distribution of the weights of the method (A.1, A.2.2, B.1, B.2.2)}

The weights of the method refer to the importance that the decision-makers give to the short-term criteria $\left(W_{i}\right)$, the project variables $\left(w_{i r}\right)$, the social goals $\left(W_{k}\right)$ and social indicators $\left(w_{k v}\right)$. For these weights, a uniform probability distribution is derived from the variation of the decision-makers' results. The importance of each criterion and social goal is related to the rest of their set and must add up to $100 \%$. For this reason, a correlation analysis can be incorporated into the distribution of the set. In this case the distribution of the set depends on the weight of greatest variability. Later, the resulting weights are standardized (Gervasio and Simoes da Silva 2012). This way, the uniform accumulated distributions of each weight set are determined for a limited number of experts. In this case, the distribution represents the probable variation space of the weight to use for different random iterations.

\subsection{Preparation of the uncertain variables $\left(r_{i}\right)$ and indicators $\left(v_{k}\right)($ A.2.1 - B.2.1)}

The input data for the evaluation of each criterion and social goal are conditional upon the information from each project and its location context. In dealing with the uncertainty, the decision-makers intervene in three aspects: (1) they identify the state of uncertainty of each variable $\left(r_{i}\right)$ or conditioning factor of the zone $\left(c_{i r}\right)$; (2) they quantify the maximum, minimum and most probable value of each uncertain $r_{i}$ or $c_{i r}$; and (3) they value the improvement potential of each indicator through $Z_{k v}$ and $C_{k v}$ per project. From the uncertain values of $r_{i}$ or $c_{i r}$, the parameters $\alpha$ and $\beta$ can be determined, which in turn determine the beta PERT distribution of each uncertain element. Eqs. [3] and [4] represent the parameters $\alpha$ and $\beta$ of a beta PERT distribution for the maximum $\left(X_{\max }\right)$, 
minimum $\left(X_{\min }\right)$ and most probable $\left(X_{\text {mod }}\right)$ values of each uncertain $r_{i}$ or $c_{i r}$ by project (Jato-Espino et al. 2014).

$$
\begin{aligned}
& \alpha=\frac{2 \cdot\left(X_{\max }+4 \cdot X_{\bmod }-5 \cdot X_{\min }\right)}{3 \cdot\left(X_{\max }-X_{\min }\right)} \cdot\left[1+4 \cdot \frac{\left(X_{\bmod }-X_{\min }\right) \cdot\left(X_{\max }-X_{\bmod }\right)}{\left(X_{\max }-X_{\min }\right)^{2}}\right] \\
& \beta=\frac{2 \cdot\left(5 \cdot X_{\max }-4 \cdot X_{\bmod }-X_{\min }\right)}{3 \cdot\left(X_{\max }-X_{\min }\right)} \cdot\left[1+4 \cdot \frac{\left(X_{\bmod }-X_{\min }\right) \cdot\left(X_{\max }-X_{\bmod }\right)}{\left(X_{\max }-X_{\min }\right)^{2}}\right]
\end{aligned}
$$

On the other hand, an accumulated uniform distribution may be associated with the discrete values given by the set of experts in each indicator, where the evolution of each indicator depends on the improvement potential because of project $Z_{k v}$ and the current weakness of the indicator in the zone $C_{k v}$.

\subsection{Assessment scenarios of the short-term social criteria (A.3)}

The utility function of Eq. [1] is used to re-assess the satisfaction level of the short-term criteria. Strategically, those criteria that one wishes to promote tend to use a lowdemand curve (concave curve). In case of aspiring to criteria with a higher demand or with no clear trend, the convex or linear curves are more appropriate, respectively. Operationally, where there are project alternatives with similar conditions, high-demand curves facilitate the differentiation. Fig. 2 illustrates three scenarios of smoothed $V_{i}$ functions of high, moderate and low demand. These scenarios are used to estimate the sensitivity of the final decision-making method.

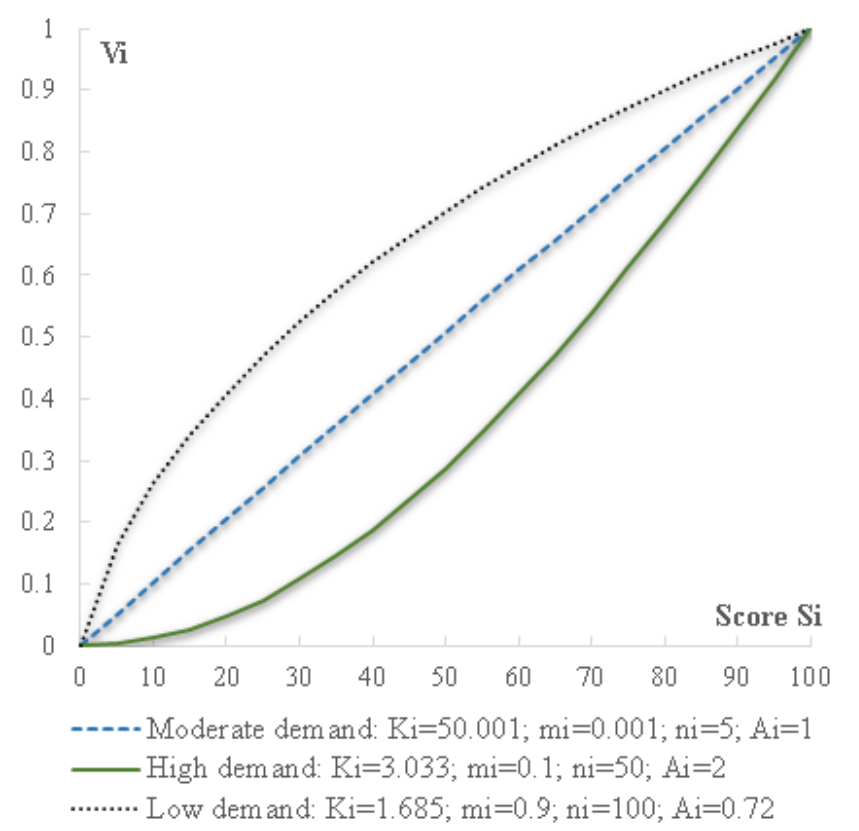

Fig.2 Curve of $V i$ value for high, moderate and low social requirement

\subsection{Propagation of uncertainty in the method to obtain the social improvement indices $(\mathrm{A.4}, \mathrm{B.4})$}

STSI and LTSI are obtained from the values $V_{i}$ and $S_{k}{ }^{l t}$ and from the weights of the criteria $W i$ and from the social goals $W_{k}$, respectively. The accumulated probability of 
the weights, variables and indicators must be determined. Then, the Monte Carlo method propagates the uncertainty in the processes of the method. This method generates pseudo-random probabilities according to the specific probability distribution of each uncertain element. This is to say, in each uncertain element a random value ( 0 to 1 ) is generated and a specific value is determined through the inverse of its accumulated probability. Thus, a sample of iterations of STSI and LTSI is generated with respect to the uncertainty associated with a project. After several tests for this model, it has been identified that with 5,000 iterations a significant convergence is already reached and with a low computing cost. The confidence intervals and histograms for each index are results obtained from this procedure.

\subsection{Determination of probability of each prioritized alternative (C.1)}

On this point, the infrastructure project alternatives $j$ selected derive from the simultaneous evaluation of STSI and LTSI. The method optimizes projects $j$ according to the smaller distance $d_{\infty}$ through compromise programming (Eq [2]). A set of STSI and LTSI values represents an infrastructure project. In ascending order from $d_{\infty}$, the infrastructure projects are prioritized for each iteration. The projects selected in each position of the order of priority correspond to the mode of the iteration sample. On this point, the probability of each project selected is obtained in a position of the order of priority. High probabilities confer greater reliability on the decision-making of a project with a better social contribution. This procedure is repeated for each scene (high, moderate and low social requirement) established in point 5.3 of this article.

\section{Case study}

A case study is presented to illustrate the method and its practical application. The case study is based on 6 alternatives that arise with two options to improve interurban roads applied in three regions of El Salvador. The two improvement options are technically applicable to all the location sectors. In this context, the public administration must prioritize the infrastructure alternatives during the viability phase of the life cycle. To do so, the social contribution of each alternative is taken into account. The following subsections present the decision-making structure, the background and the treatment of uncertainty for the case study. Other background of the application of the method in the case study can be consulted in Sierra et al. (2017).

\subsection{Structure for decision-making}

The selection of criteria $(i)$, project variables $\left(r_{i}\right)$, conditioning factors $\left(c_{r i}\right)$, social goals $(k)$ and indicators $\left(v_{k}\right)$ forms the decision-making structure. This structure takes into account the incidence of the road infrastructure in the context of El Salvador. A field study as well as a review of projects, norms and the regional database were considered in the definition of the structure. The validation of the structure derives from the consensus of 29 multidisciplinary decision-makers. The background of the decisionmakers and the exploratory study are set out in Sierra et al. (2017). The first five columns of Table 1 show the short-term decision-making structure. Table 1 also presents the transference functions according to stage A.2.3 of the method. In the long term, three social goals are selected: socioeconomic (local level) $(k=1)$, education $(k=2)$ and health care $(k=3)$. From these the per-capita income indicators $\left(\mathrm{v}_{1}\right)$, years of 
schooling $\left(v_{2} l\right)$, percentage of the population with secondary education $\left(v_{2} 2\right)$ and life expectancy $\left(v_{3}\right)$ are derived according to each social goal.

Table 1: Short-term decision-making structure of the case of study

\begin{tabular}{|c|c|c|c|c|c|c|c|}
\hline$i$ & $\begin{array}{l}\text { Crite- } \\
\text { rion }\end{array}$ & $R$ & $\begin{array}{l}\text { Varia- } \\
\text { ble }\end{array}$ & \multicolumn{2}{|c|}{ Interaction items } & $\begin{array}{l}\mathrm{Na}- \\
\text { ture }^{1}\end{array}$ & Transference function $\left(\mathrm{x} 10^{2}\right)$ \\
\hline \multirow[t]{12}{*}{1} & \multirow{12}{*}{ 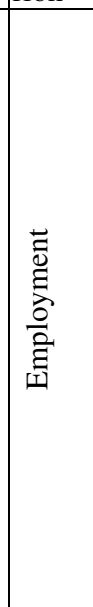 } & \multirow[t]{6}{*}{1} & \multirow{6}{*}{$\stackrel{\infty}{\Xi}$} & & $\mathrm{N}^{\circ}$ contracts & $\mathrm{S}$ & \multirow{6}{*}{$Y_{11}^{c p} \cong\left[\frac{\left(X_{11}-c_{112}\right)}{\left(c_{111}-c_{112}\right)}\right] \cdot\left[\frac{c_{113}-c_{115}}{c_{114}-c_{115}}\right]$} \\
\hline & & & & c111 & Max. hiring & $\mathrm{D}$ & \\
\hline & & & & $c_{112}$ & Min. hiring & $\mathrm{D}$ & \\
\hline & & & & $c_{113}$ & Local unemployment rate & $\mathrm{S}$ & \\
\hline & & & & $c_{114}$ & $\begin{array}{l}\text { Max regional } \\
\text { unemployment rate }\end{array}$ & $\mathrm{D}$ & \\
\hline & & & & $c_{115}$ & $\begin{array}{l}\text { Min regional } \\
\text { unemployment rate }\end{array}$ & $\mathrm{D}$ & \\
\hline & & 2 & & $X_{12}$ & Hiring months & $\mathrm{S}$ & $\left.\sim\left(X_{12}-c_{122}\right)\right]\left[c_{123}-c_{125}\right]$ \\
\hline & & & & $c_{121}$ & Historic max. hiring period & $\mathrm{D}$ & $\left.\overline{\left(c_{121}-c_{122}\right)}\right] \cdot\left[\overline{c_{124}-c_{125}}\right]$ \\
\hline & & & 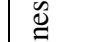 & $c_{122}$ & Historic min. hiring period & $\mathrm{D}$ & \\
\hline & & & $\bar{\nabla}$ & $c 123$ & Local unemployment rate & $\mathrm{S}$ & \\
\hline & & & $\stackrel{\widetilde{D}}{0}$ & $c_{124}$ & $\begin{array}{l}\text { Max regional } \\
\text { unemployment rate }\end{array}$ & $\mathrm{D}$ & \\
\hline & & & & $c_{125}$ & $\begin{array}{l}\text { Min regional } \\
\text { unemployment rate }\end{array}$ & $\mathrm{D}$ & \\
\hline 2 & & 1 & & $X_{21} 1$ & $\mathrm{~N}^{\circ}$ properties affected & $\mathrm{D}$ & $c p \sim\left[\quad\left(X_{211} \cdot X_{212}\right)\right]$ \\
\hline & & & & $X_{21 \_2}$ & Right of way assessment & $S$ & 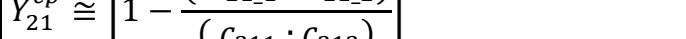 \\
\hline & & & $\stackrel{0}{\stackrel{0}{0}}$ & $c_{211}$ & $\begin{array}{l}\text { Max historic right of way } \\
\text { assessment }\end{array}$ & $\mathrm{D}$ & 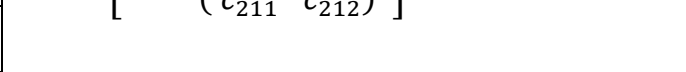 \\
\hline & & & & $c 212$ & $\begin{array}{l}\text { Max historic } \mathrm{N}^{\circ} \text { properties } \\
\text { affected (or by consensus) }\end{array}$ & $\mathrm{D}$ & \\
\hline & & 2 & & $X_{22 \_1}$ & $\mathrm{~N}^{\circ}$ vulnerable families & $\mathrm{D}$ & $V^{c p} \sim\left[1 \quad\left(X_{22 \_1} \cdot X_{22 \_3}+X_{22 \_2} \cdot X_{22 \_4}\right)\right]$ \\
\hline & $\overline{7}$ & & $\stackrel{\tilde{z}}{=}$ & $X_{22 \_2}$ & $\mathrm{~N}^{\circ}$ non-vulnerable families & $\mathrm{D}$ & $Y_{22} \cong\left|1-\frac{1}{5 \cdot c_{221}}\right|$ \\
\hline & : & & 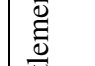 & $X_{22 \_3}$ & $\begin{array}{l}\text { Degree of mitigation of } \\
\text { vulnerable families }\end{array}$ & $\mathrm{D}$ & \\
\hline & 胥 & & 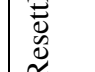 & $X_{22 \_4}$ & $\begin{array}{l}\text { Degree of mitigation of } \\
\text { non-vulnerable families }\end{array}$ & D & \\
\hline & 离 & & & $c_{221}$ & $\begin{array}{l}\text { Max historic } \mathrm{N}^{\circ} \text { resettled } \\
\text { families (or by consensus) }\end{array}$ & $\mathrm{D}$ & \\
\hline & $\overbrace{}^{2}$ & $\begin{array}{c}3 \\
\text { to }\end{array}$ & & $X_{2 r_{-} l}$ & $\begin{array}{l}\% \text { travel time reduction } \\
\text { limited to } 75 \%\end{array}$ & $S$ & If $X_{2 r_{-} 2} \leq\left(c_{2 r 3}-c_{2 r 2}\right) \&\left(c_{2 r 3}>c_{2 r 2}\right)$ then \\
\hline & & 8 & 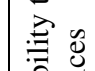 & $X_{2 r} r_{-}$ & $\begin{array}{l}\text { Absolute increase demand } \\
\text { service year } 2\end{array}$ & $\mathrm{~S}$ & $Y_{2 r}^{c p} \cong\left[\frac{X_{2 r_{-} 1} c_{2 r 1}}{75 \cdot 3}\right] \cdot\left[1-\frac{X_{2 r_{-} 2}}{\left(c_{2 r 3}-c_{2 r 2}\right)}\right]$ \\
\hline & & & 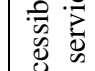 & $c 2 r l$ & $\begin{array}{l}\text { Frequency existing public } \\
\text { transport }^{2}\end{array}$ & $\mathrm{D}$ & In other cases $Y_{2 r}^{c p} \cong 0$ \\
\hline & & & 过 & $c_{2 r 2}$ & Current demand for service & $\mathrm{D}$ & \\
\hline & & & & $c 2 r 3$ & Capacity of the service & $\mathrm{D}$ & $\begin{array}{l}\text { Con: } r=3 \text { Primary ed.; } r=4 \text { Secondary ed.; } r=5 \text { Health unit; } r=6 \\
\text { Hospital; } r=7 \text { Commercial area; } r=8 \text { Police and emergency. }\end{array}$ \\
\hline 3 & & 1 & & $X_{31} 1$ & $\begin{array}{l}\text { Months construction of the } \\
\text { project, fewer than } 24\end{array}$ & $S$ & $\left.X_{31 \_1} \cdot X_{31 \_2} \cdot\left(X_{31 \_3}+X_{31 \_4}+\sum_{q=1}^{5} c_{31 q}\right)\right]$ \\
\hline & & & $\stackrel{00}{\Xi}$ & $X_{31 \_2}$ & $\begin{array}{l}\text { Mean annual daily traffic } \\
\text { interval }^{4}\end{array}$ & $\mathrm{D}$ & $24 \cdot 3 \cdot 7$ \\
\hline & $\vec{\Xi}$ & & 吾 & $X_{31 \_3}$ & $\begin{array}{l}\text { The work requires direct } \\
\text { access to the main } \text { road }^{5}\end{array}$ & $\mathrm{D}$ & \\
\hline & $\stackrel{\Xi}{0}$ & & 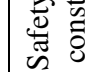 & $X_{31-4}$ & $\begin{array}{l}\text { Use of machines with } \\
\text { contiguous traffic }^{5}\end{array}$ & $\mathrm{D}$ & \\
\hline & $\begin{array}{l}\text { 島 } \\
\stackrel{0}{ \pm}\end{array}$ & & & $c 31 q$ & $\begin{array}{l}\text { Preexistence of social } \\
\text { problems in the context; } \\
\mathrm{q} \in[1-5]^{5,6}\end{array}$ & $\mathrm{D}$ & \\
\hline & 总 & 2 & $\Xi 气$ & $X_{32 \_p}$ & $\begin{array}{l}\text { Verification of applicable } \\
\text { design conditions; } \mathrm{p} \epsilon[1- \\
10]^{7,8}\end{array}$ & $\mathrm{D}$ & $Y_{32}^{c p} \cong\left[\frac{\sum_{p=1}^{10} X_{32 \_} p}{m}\right] \cdot\left[1-\sum_{z=1}^{10} c_{32 z}\right]$ \\
\hline & & & 氙 & $c 32 z$ & $\begin{array}{l}\text { Danger of the context; } \\
\mathrm{z} \in[1-10]^{5,9}\end{array}$ & $\mathrm{D}$ & With " $m$ " applicable design conditions. \\
\hline 4 & 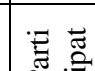 & 1 & $\underset{\Xi}{\oplus}$ & $X_{41} 1$ & $\begin{array}{l}\text { Existence of information } \\
\text { medium }^{5}\end{array}$ & D & {$\left[\left(X_{41 \_}+\frac{X_{41 \_1}}{2}\right)\right]$} \\
\hline & & & $\Sigma 2$ & $\bar{X} 41_{-} 2$ & Type of feedback ${ }^{10}$ & $\mathrm{D}$ & $\overline{c_{411}}$ \\
\hline
\end{tabular}




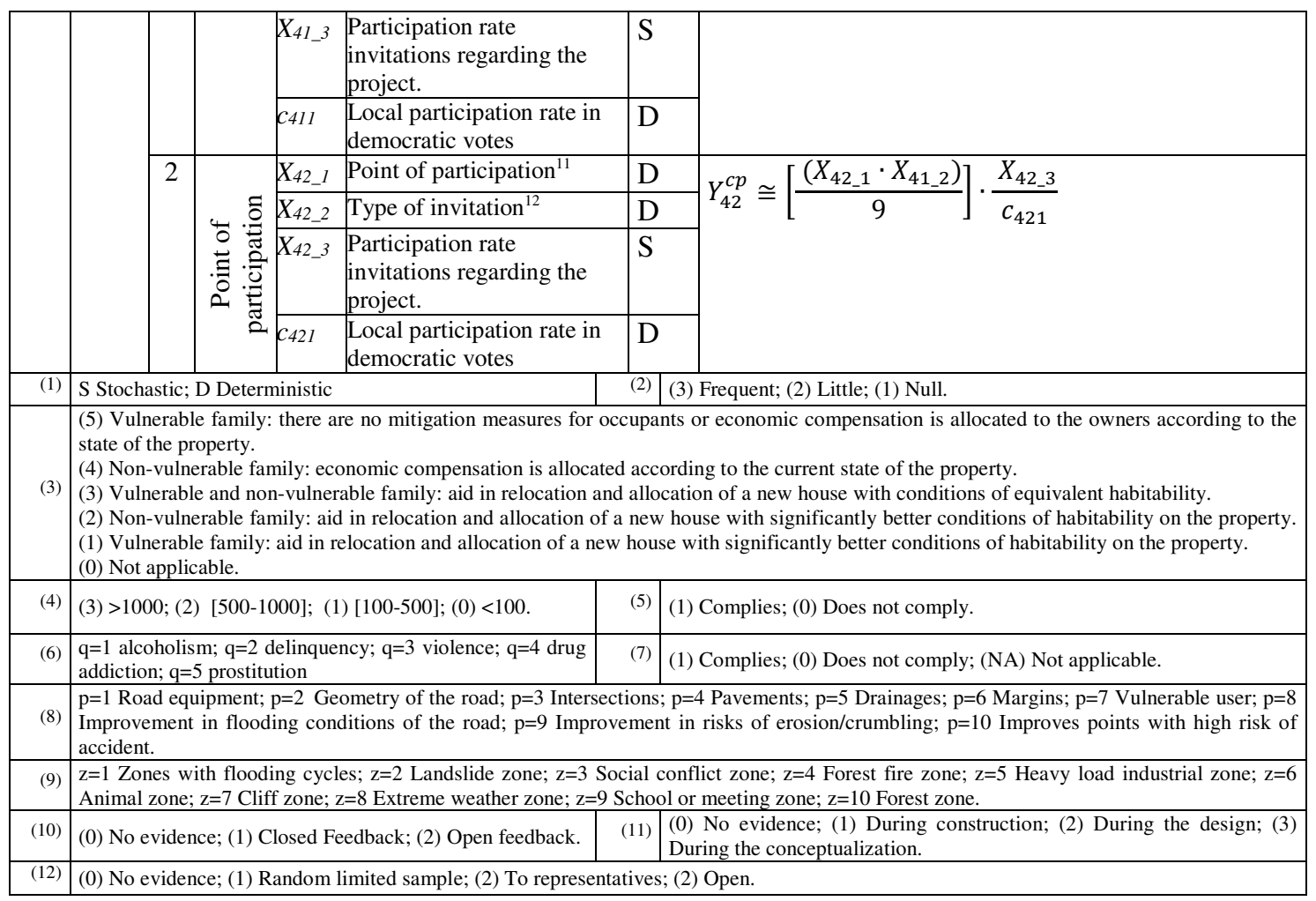

\subsection{Description of the alternatives of infrastructure projects}

The improvement of road network infrastructures in El Salvador is currently at a crucial stage of its plan to revitalize local economies (UNDP 2010). To illustrate this study, two intervention options were selected. Option A is a partial improvement with works of transverse, longitudinal drainage and permanent maintenance of the stone platforms or patching the existing pavement; in this case, the operating speed does not exceed 40 $\mathrm{km} / \mathrm{h}$. Option B involves an overall improvement and incorporates road widening works to a standard of $7 \mathrm{~m}$ and paving in hydraulic concrete; in this case, the operating speed does not exceed $90 \mathrm{~km} / \mathrm{h}$. The improvement options can be applied on the base lines of each zone represented in Table 2 and characterized in the following:

- Zone 1: There is currently an inter-city road paved in concrete with a high level of deterioration. The road connects a highly developed city and a local town with a high population and which is seasonally isolated (winter). The improvement benefits 1,500 inhabitants. The mean annual daily traffic on the road is 800 vehicles. The length to improve is $7 \mathrm{~km}$. The local economy depends on the agro-fishery industry.

- Zone 2: The rural road connects 5 local areas and involves a benefit for 2,680 inhabitants. The road varies in width, with a gravel platform, difficult accessibility and a high accident rate in winter. The mean annual daily traffic is 500 vehicles and the length to improve is $15 \mathrm{~km}$. The local economy is based on the tourist potential in the mountain zone. The zone presents unexploited historico-cultural conditions.

- Zone 3: It is an interurban road that connects 2 local areas and a city of average development. In the medium term already existing harbor facilities will begin operating. The road has loose pebbles and a deteriorated drainage system. The improvement involves a benefit for 600 inhabitants. The mean annual daily traffic is 300 vehicles and the length to improve is $7 \mathrm{~km}$. The zone is located in the coastal 
sector with a low tourist development. The local economy is based on agriculture and fishing.

Table 2: Location background of assessment contexts

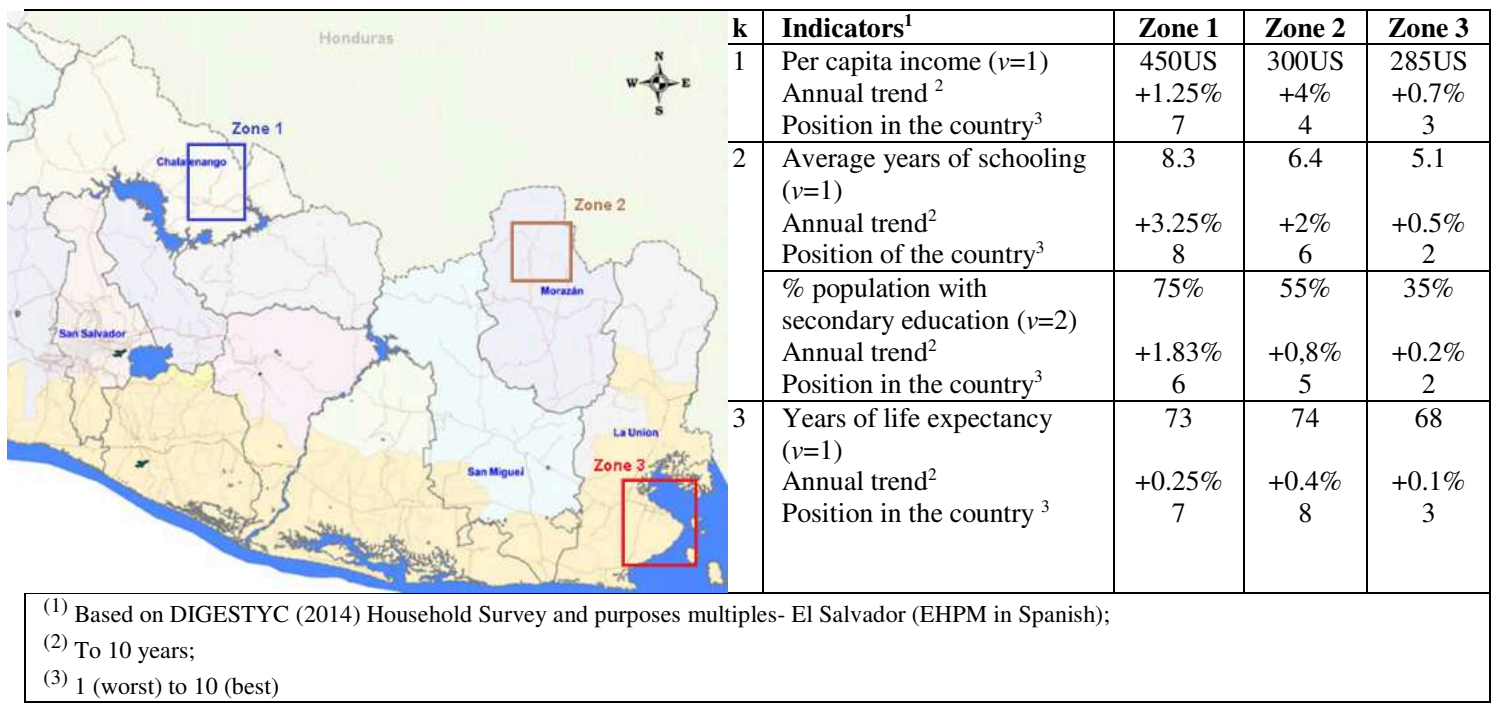

Table 3 presents the background for the evaluation of each short-term alternative. The background derives from a review of the project documentation, field studies, a review of comparable infrastructure projects and interviews with experts. The value of the uncertain elements comes from the consultation with the expert decision-makers with respect to each alternative.

Table 3: Synthesis of the background of the alternatives for short-term evaluation

\begin{tabular}{|c|c|c|c|c|c|c|}
\hline \multirow{2}{*}{$\begin{array}{l}\text { Inputs } i, r \\
\text { and } c_{i r}\end{array}$} & \multicolumn{6}{|c|}{ Project versus zone } \\
\hline & A_1 & B_1 & A_2 & B_2 & A_3 & B_3 \\
\hline \multicolumn{7}{|c|}{ Employment $(i=1)$} \\
\hline $\begin{array}{l}\text { Number of } \\
\text { monthly } \\
\text { contracts }(r=1)\end{array}$ & $\begin{array}{l}\max 66, \min 54, \\
\text { mode } 60 \text { contracts }\end{array}$ & $\begin{array}{l}\max 36, \text { min } 24, \\
\text { mode } 30 \text { contracts }\end{array}$ & $\begin{array}{l}\max 77, \text { min } 63, \\
\text { mode } 70 \text { contracts }\end{array}$ & $\begin{array}{l}\max 54, \min 36 \\
\text { mode } 45 \text { contracts }\end{array}$ & $\begin{array}{l}\max 55, \min 45, \\
\text { mode } 50 \text { contracts }\end{array}$ & $\begin{array}{l}\max 42, \min 28, \\
\text { mode } 35 \text { contracts }\end{array}$ \\
\hline $\begin{array}{l}\text { Regional history } \\
\text { of contracts by } \\
\text { project type } \\
{\left[c_{111}-c_{112}\right]}\end{array}$ & \multicolumn{2}{|c|}{$[18-80]$} & \multicolumn{2}{|c|}{$[18-80]$} & \multicolumn{2}{|c|}{$[18-80]$} \\
\hline $\begin{array}{l}\text { Construction } \\
\text { deadline }(r=2)\end{array}$ & $\begin{array}{l}\min 2, \quad \text { max } \quad 12 \\
\text { (includes } \\
\text { maintenance), } \\
\text { mode } 3 \text { months }\end{array}$ & $\begin{array}{l}\min 3, \quad \text { max } 6 \\
\text { mode } 4 \text { months; }\end{array}$ & $\begin{array}{l}\min 3, \quad \max \quad 12 \\
\text { (includes } \\
\text { maintenance), } \\
\text { mode 4 months }\end{array}$ & $\begin{array}{l}\text { min } 5, \quad \text { max } \\
\text { mode } 6 \text { months }\end{array}$ & $\begin{array}{l}\min 2, \quad \text { max } 12 \\
\text { (includes } \\
\text { maintenance), } \\
\text { mode } 3 \text { months }\end{array}$ & $\begin{array}{l}\min 3, \text { max } 6, \text { mode } \\
4 \text { months. }\end{array}$ \\
\hline $\begin{array}{l}\text { Regional history } \\
\text { deadline by } \\
\text { project type } \\
{\left[c_{121}-c_{122}\right]}\end{array}$ & \multicolumn{2}{|c|}{$[2-24]$} & \multicolumn{2}{|c|}{$[2-24]$} & \multicolumn{2}{|c|}{$[2-24]$} \\
\hline $\begin{array}{l}\text { Local } \\
\text { unemployment } \\
\left(\mathrm{c}_{113}=\mathrm{c}_{123}\right) \\
\text { Max and min } \\
\text { national } \\
\text { unemployment } \\
{\left[c_{114^{-}} c_{115}\right]=\left[c_{124^{-}}\right.} \\
\left.c_{125}\right]\end{array}$ & \multicolumn{2}{|c|}{$\begin{array}{c}\max 6.53 \%, \min 5.53 \%, \text { mode } 6.01 \% ; \\
{[4.1 \%-6.8 \%]}\end{array}$} & \multicolumn{2}{|c|}{$\begin{array}{c}\max 5.82 \%, \min 4.21 \%, \text { mode } 4.55 \% ; \\
{[4.1 \%-6.8 \%]}\end{array}$} & \multicolumn{2}{|c|}{$\begin{array}{c}\max 5.85 \min 4.98 \%, \text { mode } 5.78 \% ; \\
{[4.1 \%-6.8 \%]}\end{array}$} \\
\hline \multicolumn{7}{|c|}{ Property and habitability $(i=2)$} \\
\hline $\begin{array}{l}\text { Rights of way } \\
(r=1)\end{array}$ & no evidence & no evidence & no evidence & $\begin{array}{l}\text { Right of way for } \\
\text { min } 100 \text {, max } 200 ; \\
\text { mode } 150 \text { mil US } \\
\text { and } 40 \text { properties }\end{array}$ & no evidence & $\begin{array}{l}\text { Right of way for } \\
\text { min } 45 \text {, max } 80, \\
\text { mode } 60 \text { mil US } \\
\text { and } 25 \text { properties }\end{array}$ \\
\hline
\end{tabular}




\begin{tabular}{|c|c|c|c|c|c|c|}
\hline \multirow{2}{*}{$\begin{array}{l}\text { Inputs } i, r \\
\text { and } c_{i r}\end{array}$} & \multicolumn{6}{|c|}{ Project versus zone } \\
\hline & A_1 & B_1 & A_2 & B_2 & A_3 & B_3 \\
\hline & & & & affected & & affected \\
\hline $\begin{array}{l}\text { Max historic } \\
\text { value paid for } \\
\text { rights of way } \\
\left(c_{211}\right)\end{array}$ & 1 mill.US & 1 mill.US & 1 mill.US & 1 mill.US & 1 mill.US & 1 mill.US \\
\hline $\begin{array}{l}\text { Max tolerable } \\
\text { affected } \\
\text { properties } \\
\text { (consensus) }\left(c_{212}\right)\end{array}$ & 250 & 250 & 250 & 250 & 250 & 250 \\
\hline $\begin{array}{l}\text { Resettlements } \\
(r=2)\end{array}$ & no evidence & no evidence & no evidence & $\begin{array}{l}4 \quad \text { vulnerable } \\
\text { families; Assists in } \\
\text { relocation under } \\
\text { equal conditions }\end{array}$ & no evidence & no evidence \\
\hline $\begin{array}{l}\text { Max consensus } \\
\text { of resettled } \\
\text { families }\left(c_{221}\right)\end{array}$ & 50 & 50 & 50 & 50 & 50 & 50 \\
\hline $\begin{array}{l}{ }^{1} \text { Current } \\
\text { accessibility to } \\
\text { community } \\
\text { services }\left(r_{-} l\right) \text { : } \\
\text { Primary education } \\
\text { center }(r=3) ; \\
\text { Secondary education } \\
\text { center }(r=4) \text {; Health } \\
\text { center }(r=5) \text {; Hospital } \\
(r=6) \text {; Commerce } \\
(r=7) ; \text { Police }(r=8)\end{array}$ & \multicolumn{2}{|c|}{$\begin{array}{l}\text { Rural health services, elementary school, } \\
\text { police are available in local area at } 6 \mathrm{~km} \text {; } \\
\text { (min 7', mode 9' max 15'); Secondary } \\
\text { school, hospital, major commerce at } 15 \\
\mathrm{~km} ;\left(\text { min } 18 \text { ', mode 23', max } 35^{\prime}\right) \text { by car to } \\
\text { the most disadvantaged core population } \\
\text { that uses the road }\end{array}$} & \multicolumn{2}{|c|}{$\begin{array}{l}\text { Rural health services, elementary school, } \\
\text { police are available in local area at } 10 \\
\mathrm{~km} ;\left(\text { min } 11, \text { mode } 15^{\prime} \text { max } 15^{\prime}\right) \text {; } \\
\text { Secondary school, hospital, major } \\
\text { commerce at } 30 \mathrm{~km} ;\left(\text { min } 40^{\prime}, \text { mode } 45^{\prime},\right. \\
\left.\text { max } 50^{\prime}\right) \text { by car to the most disadvantaged } \\
\text { core population }\end{array}$} & \multicolumn{2}{|c|}{$\begin{array}{l}\text { Rural health services, elementary school, } \\
\text { police are available in local area at } 4 \mathrm{~km} \text {; } \\
\left.\text { (min } 4{ }^{\prime}, \text { mode } 6^{\prime} \text { max } 10^{\prime}\right) \text {; Secondary } \\
\text { school, hospital, commerce at } 30 \mathrm{~km} \text {; } \\
\left.\text { (min } 40^{\prime} \text {, mode } 45^{\prime}, \text { max } 50^{\prime}\right) \text { by car to the } \\
\text { most disadvantaged core population }\end{array}$} \\
\hline $\begin{array}{l}\text { Current } \\
\text { frequency of } \\
\text { public transport } \\
\left(c_{2 r 1}\right) \\
\end{array}$ & \multicolumn{2}{|c|}{$\begin{array}{l}\text { Public transportation } 2 \text { times per } \\
\text { day. }\end{array}$} & \multicolumn{2}{|c|}{$\begin{array}{l}\text { Public transportation } 6 \text { times per } \\
\text { day. }\end{array}$} & \multicolumn{2}{|c|}{$\begin{array}{l}\text { Public transportation } 2 \text { times per } \\
\text { day }\end{array}$} \\
\hline $\begin{array}{l}\text { Increased } \\
\text { demand for } r \\
\text { service due to the } \\
\text { project }\left(r_{-} 2\right): \\
(\max , \text { mode }, \text { min })\end{array}$ & $\begin{array}{l}r=3(20,15,5 \\
\text { registrations }) ; r=4 \\
(25,20,5 \\
\text { registrations }) ; r=5 \\
(13,10,0 \\
\text { consultations/day); } \\
r=6(20,10,0 \\
\text { beds }) ; r=7(20,15, \\
5 \text { events })\end{array}$ & $\begin{array}{l}r=3 \quad(50, \quad 40,20 \\
\text { registrations }) ; r=4 \\
(15,10, \quad 0 \\
\text { registrations }) ; r=5 \\
(40,25,10 \\
\text { consultations/day); } \\
r=6 \quad(40, \quad 30,10 \\
\text { beds }) ; \quad r=7 \quad(50,30, \\
10 \text { events })\end{array}$ & $\begin{array}{l}r=3 \quad(60, \quad 50,40 \\
\text { registrations }) ; r=4 \\
(40,20, \quad 5 \\
\text { registrations }) ; \quad r=5 \\
(25,15,5 \\
\text { consultations/day }) ; \\
r=6 \quad(10,5,0 \\
\text { beds }) ; r=7 \quad(30,20, \\
5 \text { events })\end{array}$ & $\begin{array}{lr}r=3 \quad(85,80,75 \\
\text { registrations }) ; & r=4 \\
(55,45, \quad 30 \\
\text { registrations }) ; & r=5 \\
(90,70,50 & \\
\text { consultations/day); } & r=6 \quad(35,25,5 \\
\text { beds }) ; \quad r=7 \\
(100,50,20 & \text { events })\end{array}$ & $\begin{array}{l}r=3 \quad(75, \quad 70,50 \\
\text { registrations }) ; \quad r=4 \\
(15,10, \quad 0 \\
\text { registrations }) ; r=5 \\
(25,20,5 \\
\text { consultations/day); } \\
r=6 \quad(20, \quad 10, \quad 0 \\
\text { beds }) ; \quad r=7 \quad(30,25, \\
5 \text { events })\end{array}$ & $\begin{array}{l}r=3(180,150,100 \\
\text { registrations }) ; r=4 \\
(55,45, \quad 30 \\
\text { registrations); } r=5 \\
\text { (40,30,10 } \\
\text { consultations/day); } \\
r=6 \quad(50,40, \quad 30 \\
\text { beds); } \quad r=7 \\
(70,50,15 \text { events })\end{array}$ \\
\hline $\begin{array}{l}\text { Current service } \\
\text { demand }\left(c_{2 r 2}\right) \text { : }\end{array}$ & \multicolumn{2}{|c|}{$\begin{array}{l}\text { Primary Sch.( } 305 \text { registrations); } \\
\text { Secondary Ed. }(2500 \text { registrations }) ; \\
\text { Health unit ( } 385 \text { consultations/day); } \\
\text { Hospital ( } 250 \text { camas); Police }(2100 \\
\text { events })\end{array}$} & \multicolumn{2}{|c|}{$\begin{array}{l}\text { Primary Sch. }(850 \quad \text { registrations }) ; \\
\text { Secondary Ed. }(800 \quad \text { registrations }) ; \\
\text { Health unit }(100 \text { consultations } / \text { day }) ; \\
\begin{array}{l}\text { Hospital }(150 \text { camas }) ; \text { Police }(2000 \\
\text { events })\end{array}\end{array}$} & \multicolumn{2}{|c|}{ 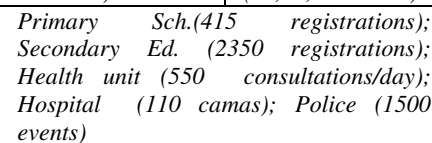 } \\
\hline $\begin{array}{l}\text { Projected service } \\
\text { capacity }\left(c_{2 r 3}\right) \text { : }\end{array}$ & \multicolumn{2}{|c|}{ 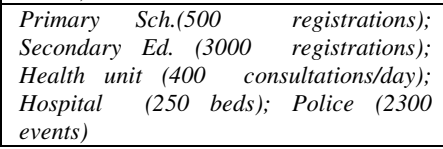 } & \multicolumn{2}{|c|}{ 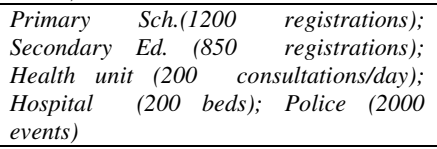 } & \multicolumn{2}{|c|}{ 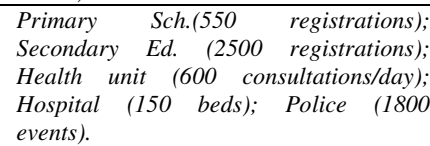 } \\
\hline \multicolumn{7}{|c|}{ Safe environment $(i=3)$} \\
\hline $\begin{array}{l}\text { Safety during } \\
\text { construction } \\
\text { work }(r=1)\end{array}$ & \multicolumn{2}{|c|}{$\begin{array}{l}\text { Work with machines and equipment with } \\
\text { contiguous traffic. The roads access } \\
\text { directly to a main way. There is strong } \\
\text { evidence of alcoholism and crime }\end{array}$} & \multicolumn{2}{|c|}{$\begin{array}{l}\text { Work with machines and equipment with } \\
\text { contiguous traffic }\end{array}$} & \multicolumn{2}{|c|}{$\begin{array}{l}\text { The roads access directly to a main way. } \\
\text { There is strong evidence of alcoholism } \\
\text { and crime }\end{array}$} \\
\hline $\begin{array}{l}\text { Safety in the } \\
\text { operation of } \\
\text { infrastructure } \\
(r=2)\end{array}$ & --- & $\begin{array}{l}\text { Flooding } \\
\text { conditions will be } \\
\text { reduced }\end{array}$ & --- & $\begin{array}{l}\text { Flooding } \\
\text { conditions will be } \\
\text { reduced. Improves } \\
\text { safety on the layout } \\
\text { of the track. }\end{array}$ & --- & --- \\
\hline $\begin{array}{l}\text { Zonal insecurity } \\
\text { conditions }\left(c_{32 Z}\right)\end{array}$ & \multicolumn{2}{|c|}{$\begin{array}{l}\text { Zone for agricultural burning, animals } \\
\text { and heavy transport }\end{array}$} & \multicolumn{2}{|c|}{ Presence of cliffs and extreme climate } & \multicolumn{2}{|c|}{$\begin{array}{c}\text { Number important of people walk on the } \\
\text { road }\end{array}$} \\
\hline \multicolumn{7}{|c|}{ Citizen participation $(i=4)$} \\
\hline $\begin{array}{l}\text { Means of } \\
\text { participation } \\
(r=1)\end{array}$ & no evidence & $\begin{array}{l}\text { Communal } \\
\text { meeting with } \\
\text { leaders }\end{array}$ & no evidence & $\begin{array}{l}\text { Communal meeting } \\
\text { with leaders }\end{array}$ & no evidence & $\begin{array}{l}\text { Diffusion by } \\
\text { broadcasting } \\
\text { station }\end{array}$ \\
\hline $\begin{array}{l}\text { Time and rate of } \\
\text { participation of } \\
\text { the area of direct } \\
\text { influence }(r=2) \\
(\min , \text { mode, } \max )\end{array}$ & no evidence & $\begin{array}{l}\text { During the design; } \\
\quad(1,8,10 \%)\end{array}$ & no evidence & $\begin{array}{c}\text { Conception } \\
\text { Initiative of the } \\
\text { Mayor and } \\
\text { communal leaders } \\
(5,8,12 \%)\end{array}$ & no evidence & $\begin{array}{l}\text { Construction } \\
\text { started } \\
(5,10,20 \%)\end{array}$ \\
\hline $\begin{array}{l}\text { Regional } \\
\text { democratic } \\
\text { participation rate } \\
\left(c_{411}=c_{421}\right)\end{array}$ & \multicolumn{2}{|c|}{$45.0 \%$} & \multicolumn{2}{|c|}{$40.1 \%$} & \multicolumn{2}{|c|}{$55.1 \%$. } \\
\hline
\end{tabular}




\begin{tabular}{|c|c|c|c|c|c|c|}
\hline \multirow{2}{*}{$\begin{array}{l}\text { Inputs } i, r \\
\text { and } c_{i r}\end{array}$} & \multicolumn{6}{|c|}{ Project versus zone } \\
\hline & A_1 & B_1 & A_2 & B_2 & A_3 & B_3 \\
\hline
\end{tabular}

${ }^{(1)}$ Note: Improving accessibility (travel time) is determined according to the speed of operation of the infrastructure and the distance to each center.

\subsection{Treatment of uncertainty in the case study}

The following paragraphs describe the development of the evaluation of the case study in the same sequence as the items explained in section 5 of this article. The code was written using Matlab (R2015b 64 bit) language for its flexibility and capacity in the development of algorithms.

Weight distribution for the case study (Stages A1, A2.2, B1, B2.2): Section 4 presents the procedure to determine the weights of the decision-making structure of the case study. A discrete uniform distribution of weights $W_{i}, w_{i r}, W_{k}$ and $w_{k v}$ derives from the importance determined by the 29 decision-makers. Section 4.1 sets forth this procedure. Fig. 3 shows the interquartile variations of the criteria and social goal weights of the decision-makers. The correlation coefficients are determined for each weight set from the same branch. For example, Table 4 presents the correlation coefficients of the criteria $(i)$ of the decision-making structure. The correlation coefficients condition and ensure a comparative trend in the weight distribution of a branch. For example, for an increase in the criterion $i=1$, the criteria $i=2, i=3$, and $i=4$ decrease in correlation. Then the criteria are standardized to guarantee $100 \%$ all together. Fig. 4 represents the accumulated uniform distribution of criterion $i=1$ (employability) and social goal $k=1$ (socioeconomic). This form of distribution in all the weight sets facilitates the subsequent application of the Monte Carlo method.
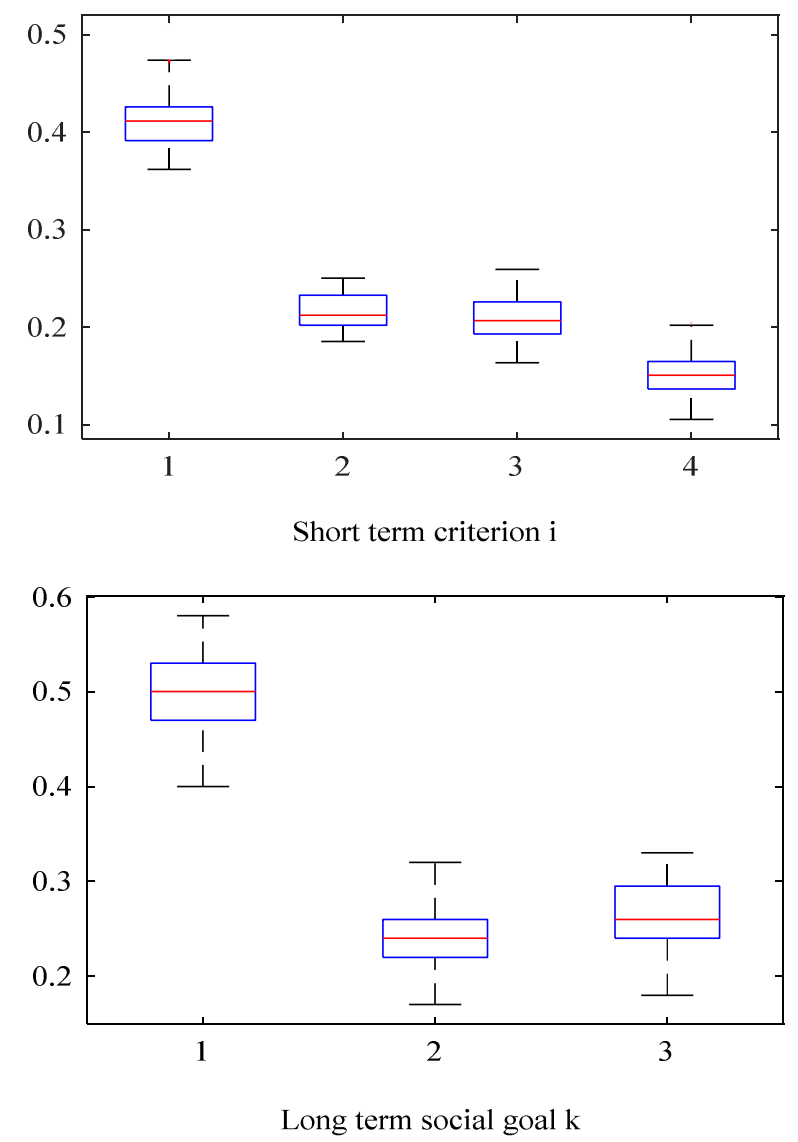

Fig. 3 Variation of weights obtained in consultation with decision-makers 
Table 4: Correlation of short-term social criterion weights

\begin{tabular}{|ccccc|}
\hline & $i=1$ & $i=2$ & $i=3$ & $i=4$ \\
$i=1$ & 1 & -0.3052 & -0.6076 & -0.1860 \\
$i=2$ & & 1 & -0.2197 & -0.2488 \\
$i=3$ & & & 1 & -0.3730 \\
$i=4$ & & & & 1 \\
\hline
\end{tabular}

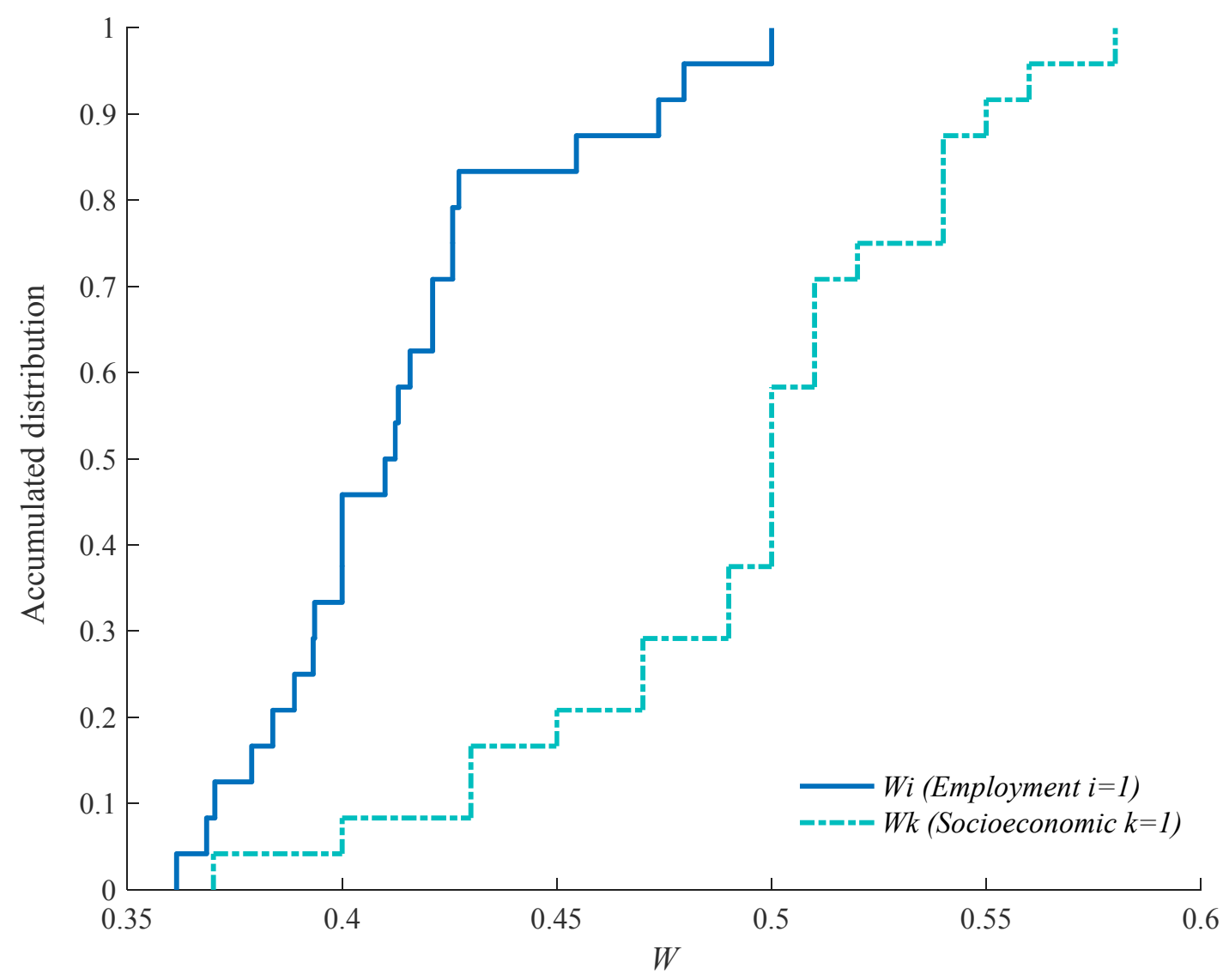

Fig. 4 Accumulated uniform distribution of employment $(i=1)$ and socioeconomic $(k=1)$

Preparation of the uncertain variables and indicators in the case study (Stages A2.1, B2.1): The values of $r_{i}$ and $c_{r i}$ considered uncertain by the decision-makers were identified in column six of Table 1 . The uncertain values of $r_{i}$ or $c_{r i}$ come from the consultation with the decision-makers or the regional database (DIGESTYC 2014) depending on availability. The maximum $\left(X_{\max }\right)$, minimum $\left(X_{\min }\right)$ and most probable $\left(X_{\text {mod }}\right)$ values were collected for each uncertain item. According to the procedure in section 5.2, Eqs. [3] and [4] determine the parameters of the beta PERT probability distribution. The values $Z_{k v}$ and $C_{k v}$ derived from the evaluation of the 29 decisionmakers as part of stage B2.3 of the proposed method. $Z_{k v}$ and $C_{k v}$ are discrete values obtained for each project and indicator $v$. Analogous to Fig. 3, the evaluations of the 29 decision-makers are grouped in an accumulated uniform distribution. 
Assessment scenario for the case study (Stage A3): In this case, three homogenous scenes of social requirement are described (high, moderate and low demand). Each scenario comes from the use of the value function of Eq. [1] according to the parameters proposed in Fig. 2. The propagation of uncertainty in the short-term evaluation process was applied to the three social requirement scenarios.

Propagation of uncertainty in the evaluation of the case study (Stages A4, B3): When propagating uncertainty, the Monte Carlo method acted in a pseudo-random way; that is to say, in each iteration a random number from 0 to 1 determines the value of the inverse accumulated distribution corresponding to each uncertain element. In this case, each project alternative was evaluated through 5,000 iterations. In other words, 5000 STSI and LTSI constituted the variation space of a project alternative.

Case study analysis and results (Stage C.1): The variation space of the STSI and LTSI for the six alternatives is shown in Fig. 5. For higher levels of demand, the short-term social improvement tended to be smaller and more concentrated. Visually the best simultaneous short and long-term contributions are produced by alternatives B2 and B3. Additionally, the high social requirement scenario facilitated differentiation of the best alternatives. Analytically, for each iteration and project alternative Eq. [2] determined a position within an order of priority. Table 5 indicates the order of priority of the set of alternatives for the three decision-making scenarios. In all the cases the first option was alternative B3 with a reliability over $90 \%$.
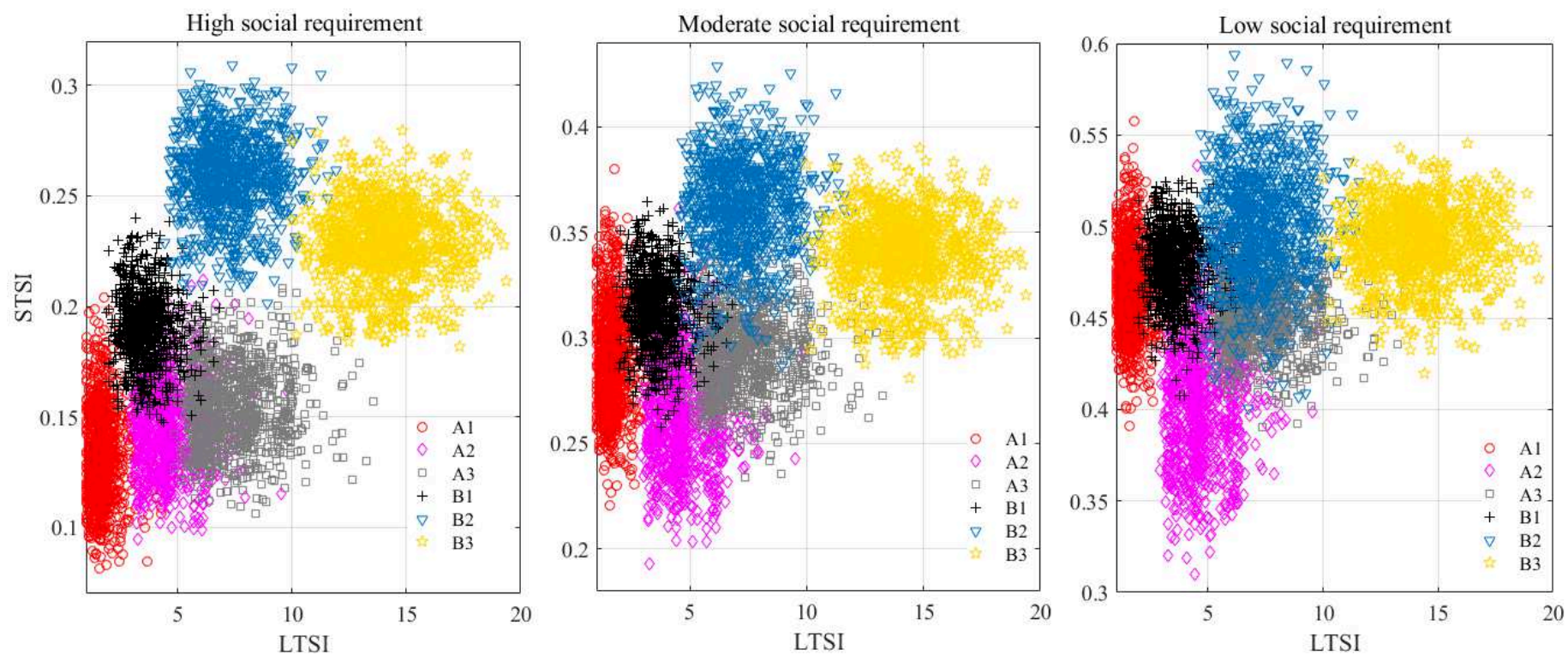

Fig. 5. Contribution to the social improvement of the infrastructure alternatives in three social requirement scenarios

Table 5: Order of priority of infrastructure alternatives

\begin{tabular}{|llcccccc|}
\hline Order of priority & 1st & 2nd & 3rd & 4th & 5th & 6th \\
\hline High & Alternative & B3 & B2 & A3 & A2 & A2 & A1 \\
demand & Probability & $\mathbf{9 7 . 7}$ & $\mathbf{9 3 . 7}$ & 52.9 & 35.1 & 40.4 & 79.9 \\
\hline Moderate & Alternative & B3 & B2 & A3 & B1 & A1 & A2 \\
demand & Probability & $\mathbf{9 4 . 7}$ & 78.3 & 57.6 & 72.3 & 83.3 & 74.3 \\
\hline Low & Alternative & $\mathbf{B 3}$ & B2 & A3 & B1 & A1 & A2 \\
demand & Probability & $\mathbf{9 2 . 6}$ & 62.9 & 48.8 & 79.9 & 94.9 & 82.5 \\
\hline
\end{tabular}


The partial results are also important in the analysis of the decision-making. Fig. 6 (left) shows a significant impact of the B3 project on the socioeconomic objective. This result is partly derived from the weight that is greater than that of the other long-term objectives (Fig. 3). Otherwise, there were no significant differences observed between the effect of B2 and B3 in the long term. Fig. 6 (right), however, shows a smaller difference between $\mathrm{B} 2$ and $\mathrm{B} 3$ in the short term. With respect to the criteria of propertyhabitability and participation, B.2 stood out over B3. Nevertheless, the long-term economy and short-term employment presented a heavy weight on the part of the decision-makers. This determined the inclination to alternative B3 over B2.

Social improvement goal

(1)Socioeconomic (2)Education (3)Health
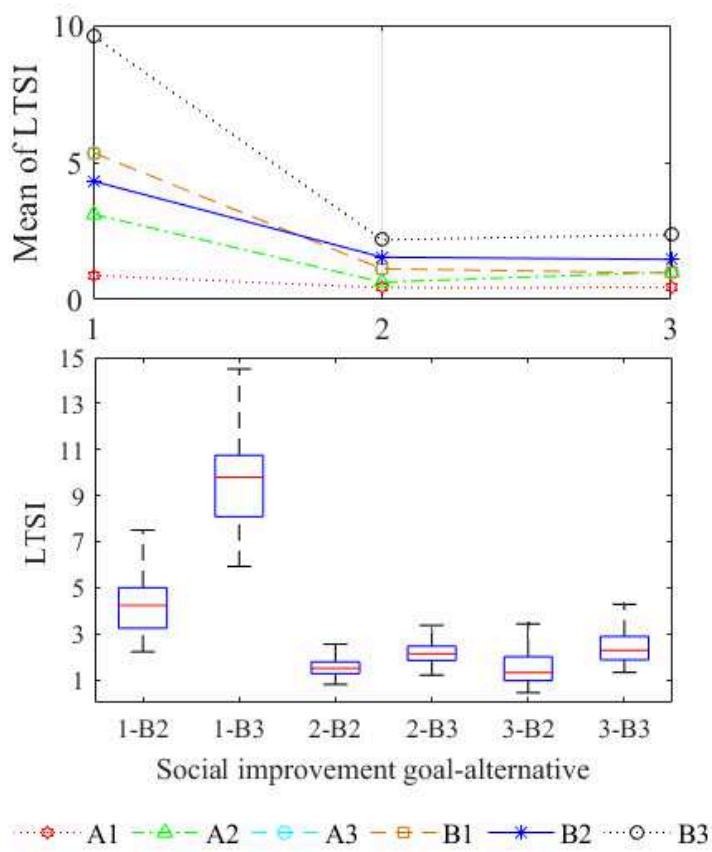

Social criteria with moderate social requirement

(1)Employment (2)Property and habitability

(3)Security environment (4)Participation
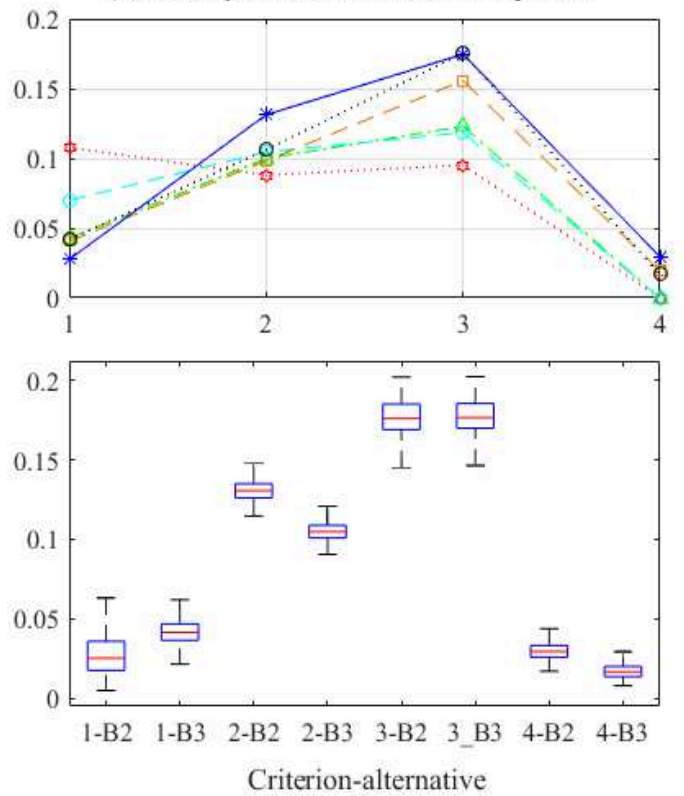

$\stackrel{\mathrm{A} 1}{\mathrm{a}} \cdot \mathrm{A} \cdot-\mathrm{A} 2-\ominus-\mathrm{A} 3-\boxminus-\mathrm{B} 1 \rightarrow \mathrm{B} 2 \cdots \odot \cdots \mathrm{B} 3$

Fig. 6 Improvement of long-term social goals (left) and short-term criteria (right) by infrastructure

\section{CONCLUSIONS}

The present article proposes a treatment of the uncertainty that complements the method to assess the social contribution of infrastructure projects. Thus, the method emphasizes the interactions of the infrastructure with the environment, short/long-term social improvement and the treatment of uncertainty in the decision-making. In its development the article focuses on the probabilistic treatment of the weights and uncertain evaluation items of the projects, the propagation of uncertainty in the method and the determination of the reliability of different social requirement scenarios.

The treatment of uncertainty is illustrated using a case study that proposes six alternatives to improve road infrastructure in different location contexts. Under this scheme the method was able to differentiate the social contribution of each alternative. In addition, a control of the uncertainty allowed the decision-makers to consider the reliability of the prioritization of an alternative. The degree of reliability is evidence of 
the repercussion of bias in the estimation of social values. The method was developed in a participatory manner. The treatment of uncertainty made it possible to integrate the opinion of various decision-makers. Thus, it is a support mechanism for the public investment agencies responsible for promoting regional development.

The adequate functioning of this proposal is limited to a suitable range of uncertainty in order to obtain results with an acceptable probability. Moreover, a suitable selection of decision-makers is advisable. If not, the reliability of the decision-making may be affected.

The proposed method is a possible estimation tool for use in the viability phase of the service life of the infrastructure. The results can complement environmental or economic sustainability assessments. This method can be applied in any geographic context, adapting the decision-making structure to the characteristics of the zone and the type of infrastructure. In the future, the intention is to investigate the transference functions and the significant elements of different infrastructures that affect the social contribution.

\section{ACKNOWLEDGMENTS}

This research was funded by the Government of Chile under the Doctoral Fellowship Program Abroad (grant CONICYT-2015/72160059) and the Spanish Ministry of Economy and Competitiveness along with FEDER funding (project BIA2014-56574R). The authors are grateful to the United Nations Development Programme and the Ministry of Public Works, Transportation, Housing and Urban Development of El Salvador, for their participation in the implementation of the proposed method (Project 00074250).

\section{REFERENCES}

Ahmadvand, M., Karami, E. (2009). “A social impact assessment of the floodwater spreading project on the Gareh-Bygone plain in Iran: a causal comparative approach”. Environ. Impact Assess., 29(2), 126-136, doi: 10.1016/j.eiar.2008.08.001.

Alarcón, B., Aguado, A., Manga, R., Josa, A. (2011). "A value function for assessing sustainability: Application to industrial building", Sustainability, 3, 35-50, doi: 10.3390/su3010035.

Cárdenas, C., Halman, J.I.M. (2016). "Coping with uncertainty in environmental impact assessments: Open techniques", Environ. Impact Assess., 60, 24-39, doi: 10.1016/j.eiar.2016.02.006.

Dasgupta, S., Tam, E.K.L. (2005). "Indicators and framework for assessing sustainable infrastructure", Can. J. Civil Eng., 32, 30-44, doi: 10.1139/104-101.

De la Cruz, M.P, Castro, A., del Caño, A., Gómez, G., Lara, M., Cartelle, J.J. (2015). “Comprehensive methods for dealing with uncertainty in assessing sustainability. Part 1: The MIVES - Monte Carlo Method", Soft Computing Applications for Renewable Energy and Energy Efficiency, 69-106, doi: 10.4018/978-1-4666-6631-3.ch004.

Diaz-Sarachaga, J.M., Jato-Espino, D., Alsulami, B., Castro-Fresno, D. (2016). "Evaluation of existing sustainable infrastructure rating systems for their application in developing countries". Ecol. Indic., 71, 491-502, doi:10.1016/j.ecolind.2016.07.033.

Dirección General de Estadísticas y Censos (DIGESTYC) (2014). Encuesta de Hogares y Propósitos Múltiples (EHPM), Gobierno de la República de El Salvador, Ministerio de Economía-El Salvador.

Dominguez-Gómez, J.A. (2016).' Four conceptual issues to consider in integrating social and environmental factors in risk and impact assessments", Environ. Impact Assess., 56 (1), 113 -119, doi: 10.1016 / j.eiar.2015.09.009.

Esteves, A.M., Vanclay, F. (2009). "Social development needs analysis as a tool for SIA to guide corporate-community investment: Applications in the minerals industry", Environ. Impact Assess., 29(2),137-145, doi: 10.1016 / j.eiar.2008.08.004. 
Gannon, C. A., Liu, Z. (1997). Poverty and Transport (No. TWU-30), World Bank, Washington, DC.

Gervasio, H., Simoes da Silva, L. (2012) "A probabilistic decision-making approach for the sustainable assessment of infrastructures", Expert Systems with Applications, 39(8), 7121-7131, doi:10.1016/j.eswa.2012.01.032.

Gómez-López, D., del Caño, A., de la Cruz, M. (2013). "Estimación temprana del nivel de sostenibilidad de estructuras de hormigón en el marco de la instrucción española EHE-08”, Inf. Constr., 65(529), 65-76, doi: 10.3989/ic.11.123.

Hallowell M., Gambatese, J. (2010). "Application of the Delphi method to CEM research", J. Constr. Eng. Manage., 136(1), 99-107, doi:10.1061/(ASCE)CO.1943-7862.0000137.

Jato-Espino, D., Rodriguez-Hernandez, J., Andrés-Valeri, V.C., Ballester-Muñoz, F. (2014) “A fuzzy stochastic multi-criteria model for the selection of urban pervious pavements", Expert Systems with Applications, 41(15), 6807-6817, doi:10.1016/j.eswa.2014.05.008.

Karami, S., Karami, E., Buys, L., Drogemuller, R. (2017). "System dynamic simulation: A new method in social impact assessment (SIA)", Environ. Impact Assess., 62(1), 25-34, doi: 10.1016/j.eiar.2016.07.009.

Labuschagne, C., Brent, A.C., (2006). "Social indicators for sustainable project and technology life cycle management in the process industry", Int. J. Life Cycle Assessment, 11, 3-15, doi:10.1065/lca2006.01.233.

Manga, R. (2005). Una Nueva Metodología para la Toma de Decisión en la Gestión de Contratación de Proyectos. PhD Thesis, Universitat Politècnica de Catalunya, Barcelona.

Pan, N.F. (2009) "Selecting an appropriate excavation construction method based on qualitative assessments", Expert Systems with Applications, 36(3), 5481-5490, doi: 10.1016/j.eswa.2008.06.097

Pellicer, E., Sierra, L.A., Yepes, V. (2016). "Appraisal of infrastructure sustainability by graduate students using an active-learning method", J. Clean. Prod., 113(1), 884-896, doi:10.1016/j.jclepro.2015.11.010.

Penadés-Pla, V., Garcia-Segura, T., Marti, J.V., Yepes, V. (2016). "A review of multi-criteria decision making methods applied to the sustainable bridge design", Sustainability, 8(12), 1295, doi:10.3390/su8121295.

Pope, J., Annandale, D., Morrison-Saunders A. (2004). "Conceptualising sustainability assessment", Environ. Impact Assess., 24(6), 595- 616, doi: 10.1016/j.eiar.2004.03.001.

Saaty, T.L., (1987). "The analytic hierarchy process - What it is and how it is used", Math. Model., 9(35), 161-176, doi:10.1016/0270-0255(87)90473-8.

Sahely, H.R., Kennedy, C., Adams, B.J., (2005). "Developing sustainability criteria for urban infrastructure systems", Can. J. Civ. Eng., 32, 72-85, doi:10.1139/104-072.

Sierra, L., Pellicer, E., Yepes, V. (2016). "Social sustainability in the life cycle of Chilean public infrastructure", J. Constr. Eng. Manage., 142(5), doi: 10.1061/(ASCE)CO.1943-7862.0001099.

Sierra, L., Pellicer, E., Yepes, V. (2017). "Method for estimating the social sustainability of infrastructure projects”, Environ. Impact. Asses., 65(1):41-53, doi: 10.1016/j.eiar.2017.02.004

Torres-Machi, C., Pellicer, E., Yepes, V., Chamorro, A. (2017). "Towards a sustainable optimization of pavement maintenance programs under budgetary restrictions”, J. Clean. Prod., 148(1), 90-102, doi: 10.1016/j.jclepro.2017.01.100.

Ugwu, O.O., Kumaraswamy, M.M., Wong, A., Ng, S.T. (2006). "Sustainability appraisal in infrastructure projects (SUSAIP): Part 1. Development of indicators and computational methods", Automation in Construction, 15(2), 239-251, doi: 10.1016/j.autcon.2005.05.006.

United Nations Development Programme - UNDP (2010). Project: Revitalize Local Economies Through the Development and Reconstruction of Public Infrastructure, Code 00074250, San Salvador - El Salvador.

http://www.sv.undp.org/content/el_salvador/es/home/operations/projects/human_development/progr ama-de-modernizacion-y-gestion-de-los-activos-de-CEPA11.html (In November 2015).

Valdés-Vásquez, R., Klotz L.E. (2013). "Social sustainability considerations during planning and design: framework of processes for construction projects", J. Constr. Eng. Manage., 139(1), 80-89, doi: 10.1061/(ASCE)CO.1943-7862.0000566.

van de Walle, D. (2009). "Impact evaluation of rural road projects". J. Dev. Eff., 1, 15-36. doi:10.1080/19439340902727701.

Vanclay, F., (2003). "International Principles for Social Impact Assessment". Impact Assess. Proj. Apprais. 21(1), 5-11, doi:10.3152/147154603781766491

Vanclay, F., (2002). "Conceptualising social impacts". Environ. Impact Assess. Rev. 22(1), 183-211, doi:10.1016/S0195-9255(01)00105-6 
Yepes, V., García-Segura, T., Moreno-Jimenez, J.M. (2015). "A cognitive approach for the multiobjective optimization of RC structural problems", Arch. Civil Mech. Eng., 15(4), 1024-1036, doi:10.1016/j.acme.2015.05.001.

Zamarron-Mieza, I., Yepes, V., Moreno-Jimenez, J.M. (2017). "A systematic review of application of multi-criteria decision analysis for aging-dam management". J. Clean. Prod., 147, 217-230, doi: 10.1016/j.jclepro.2017.01.092. 